\title{
Correction to: Intravesical sodium hyaluronate reduces severity, frequency and improves quality of life in recurrent UTI
}

\author{
Deepak Batura $^{1}\left[\right.$ D Roisin Warden ${ }^{2} \cdot$ Tumaj Hashemzehi $^{1} \cdot$ Malwina Julia Figaszewska ${ }^{1}$
}

Published online: 29 November 2019

(c) The Author(s) 2019

\section{Correction to: International Urology and Nephrology https://doi.org/10.1007/s11255-019-02315-x}

The article "Intravesical sodium hyaluronate reduces severity, frequency and improves quality of life in recurrent UTI", written by Deepak Batura, Roisin Warden, Tumaj Hashemzehi, Malwina Julia Figaszewska was originally published electronically on the publisher's internet portal (currently SpringerLink) on October 15, 2019 without open access.

The copyright of the article changed to $\odot$ The Author(s) 2019 and this article is distributed under the terms of the Creative Commons Attribution 4.0 International License (http://creativecommons.org/licen ses/by/4.0/), which permits unrestricted use, distribution and reproduction in any medium, provided you give appropriate credit to the original author(s) and the source, provide a link to the Creative Commons license, and indicate if changes were made.

The original article has been corrected.

Open Access This article is distributed under the terms of the Creative Commons Attribution-NonCommercial 4.0 International License (http://creativecommons.org/licenses/by-nc/4.0/), which permits any noncommercial use, distribution, and reproduction in any medium, provided you give appropriate credit to the original author(s) and the source, provide a link to the Creative Commons license, and indicate if changes were made.

Publisher's Note Springer Nature remains neutral with regard to jurisdictional claims in published maps and institutional affiliations.
The original article can be found online at https://doi.org/10.1007/ s11255-019-02315-x.

Deepak Batura

deepakbatura@gmail.com

1 Department of Urology, London North West University Healthcare NHS Trust, Watford Road, London HA1 3UJ, UK

2 Department of Urology, Imperial College Healthcare NHS Trust South, Wharf Road, London W2 1BL, UK 